\title{
Occurrence and Distribution of Antibiotic-Resistant Bacteria Isolated in Gaoqiao Mangrove Wetland, China
}

\author{
Li $\mathrm{Y}^{1}$, Li Q ${ }^{1}$, Sun $\mathrm{XL}^{1}$, Zhao $\mathrm{LR}^{1}$, Fan $\mathrm{HQ}^{2}$ and Zhang $\mathrm{YB}^{{ }^{* 1}}$ \\ ${ }^{1}$ Monitoring Center for Marine Resources and Environments, Guangdong Ocean University, Zhanjiang, Guangdong, \\ China \\ ${ }^{2}$ Guangxi Mangrove Research Center, Guangxi Academy of Science, Beihai, Guangxi, China
}

${ }^{*}$ Corresponding author: Zhang YB, Monitoring Center for Marine Resources and Environments, Guangdong Ocean University, Zhanjiang 524088, Guangdong, China, Fax: +86/759/2396080, Tel: +86/13790970697, E-mail:microyubin@163.com

Citation: Li Y, Li Q, Sun XL, Zhao LR, Fan HQ, et al. (2017) Occurrence and Distribution of AntibioticResistant Bacteria Isolated in Gaoqiao Mangrove Wetland, China. J Antibio Res 1(2): 202

Received Date: June 25, 2017 Accepted Date: July 11, 2017 Published Date: July 14, 2017

\begin{abstract}
Background: Antibiotic usage is very popular in the clinical treatment to infective diseases resulting in the occurrence of antibioticresistant bacteria. Antibiotics are also extensively utilized in mariculture along the coastal area including the mangroves, however, the frequent usage of antimicrobial agents can induce to the bacterial resistance, and no research on this is found to date, as a result, the occurrence and distribution was investigated in Gaoqiao mangrove wetland, China in this research.

Objective: To investigate the occurrence and distribution of antibiotic-resistant bacteria in Gaoqiao mangrove wetland, China, and access the potential effect of mangrove forest on antibiotic resistance.

Materials and Methods: The standard disc-diffusion method was employed to analyze the bacteria resistance to 12 antibiotics isolated from Gaoqiao mangrove area. Multiple Antibiotic Resistance (MAR) for bacteria was calculated.

Results: Antibiotic resistance of bacteria isolated from in mangrove assemblages and tidal channel to ampicillin, cefazolin and trimethoprim was significantly higher than to the other antibiotics $(p<0.05)$. No significant differences in percentages of antibioticresistant bacteria isolated from most sampling sites were found $(p>0.05)$. The antibiotic-resistant bacteria isolated from sediments in Avicennia marina assemblage was significantly higher than those in Aegiceras corniculatum assemblage $(p<0.05)$. Most bacteria showed MAR to 3-4 antibiotics.

Conclusion: Occurrence and distribution antibiotic-resistant bacteria in tidal-zone are usual in mangrove wetland, of which the influencing factors are very complicated.

Keywords: Antibiotic; Bacterial resistance; Occurrence and distribution; Mangrove

List of abbreviations: C: Aegiceras corniculatum; $\mathrm{C}_{1}, \mathrm{C}_{2}, \mathrm{C}_{3}$ : Serial sediment name collected from high, middle, low tidal flat in Aegiceras corniculatum assemblage, of which $\mathrm{C}_{1}, \mathrm{C}_{2}, \mathrm{C}_{3}$ mean high flat, middle flat and low flat in turn; $\mathrm{M}$ : Avicennia marina; $\mathrm{M}_{10}, \mathrm{M}_{11}, \mathrm{M}_{12}$ : Serial sediment name collected from high, middle, low tidal flat in Avicennia marina assemblage, of which $M_{1}, M_{2}, M_{3}$ mean high flat, middle flat and low flat in turn; $\mathrm{T}$ : tidal channel; $\mathrm{T}_{4}, \mathrm{~T}_{5}, \mathrm{~T}_{6}, \mathrm{~T}_{7}, \mathrm{~T}_{8}, \mathrm{~T}_{9}$ : Serial sample name collected from water of tidal channel; $\mathrm{T}_{4}, \mathrm{~T}_{5}$, $\mathrm{T}_{6}, \mathrm{~T}_{7}, \mathrm{~T}_{8}, \mathrm{~T}_{9}$ : Serial sample name collected from sediment of tidal channel; H: high tidal channel; M: middle tidal channel; L: low tidal channel; MAR: Multiple antibiotic resistance; NCCLS: National Committee for Clinical Laboratory Standards; AMP: ampicillin; CEF: cefazolin; CHP: chloramphenicol; CIP: ciprofloxacin; COS: compound sinomi; ERY: erythromycin; GEN: gentamycin; NOR: norfloxacin; NAL: nalidixic acid; POL: polymyxin-B; TET: tetracycline; TMP: trimethoprim; ANOVA: Analysis of Variance
\end{abstract}

\section{Introduction}

Rapid development of livestock-poultry cultivation and aquaculture has resulted in widespread use of antibiotics for preventing and curing diseases. In aquaculture, it is not surprised that antibiotics are routinely used at therapeutic levels to treat disease and at sub-therapeutic levels $\left(<0.2 \mathrm{~g} \cdot \mathrm{kg}^{-1}\right)$ as prophylactic agents to increase feed efficiency and improve growth rates, which lead to the widespread occurrence and dispersal of resistant bacteria to antibiotics in the habitat from mariculture [1,2]. Antibiotic residues are 
usual in the aquatic products from the developing country, which lead potentially to the resistance of bacteria to antibiotic agents [3]. We have also reported that the antibiotic resistance of bacteria isolated from shrimp hatcheries and cultural ponds on Donghai Island, China, of which the history, frequency, and dose of antibiotic utilization, as well as the chemical structure of antibiotics may play the important roles [4]. In addition, it has to be mentioned out that some maricultural ponds are usually constructed within or around the mangrove wetlands [5,6], and the previous researches held the opinion that the resistant bacteria and resistant genes in maricultural ponds could transfer to the surrounding environment by the vertical and horizontal transmission [5,7]. The mangrove wetland may act as a long-term reservoir for the antibiotic-resistant bacteria [6]. As a consequence, it is necessary to conduct some systematic and comprehensive researches on the occurrence and distribution of antibiotic-resistant bacteria in the mangrove areas.

Nowadays, a major concern associated with the antibiotic residues is the occurrence of antibiotic-resistant bacteria and genes, as well as the relationship between them in aquaculture region (including maricultural ponds and surrounding marine environment). The diverse antibiotics have been detected in the maricultural environments around the world, such as China, Vietnam, and Italy, without an exception for the mangrove wetland surrounded by maricultural ponds [4-6,8-10]. Bacterial resistance is promoted in these habitats as the response to the selective pressure from residual antibiotics [2,7]. The occurrence of antibiotic resistance among bacteria from maricultural areas was apparently promoted during the past years and may affect the coastal or marine ecosystems and human health since the residual antibiotics are inevitably transferred into the food chain [11]. Several studies pointed out that the resistant-bacteria isolated from some sediments and waters in the aquaculture ponds and surrounding marine environment to antibiotics were frequently present, such as $\beta$-lactam, sulfonamides, fluoroquinolones and tetracyclines [11-13], even the researchers reported that the percentage of antibiotic resistance was up to $59.06 \%$ in some hatcheries [12,14]. However, the occurrence of bacterial resistance and the level of resistance to drugs are linked to the complicated effective factors and do not always correlate with antibiotic concentrations in the natural ecosystems $[7,15,16]$.

The previous studies have been conducted to determine the occurrence of antibiotic residues and antibiotic-resistant bacteria in some mangrove areas [5,17]. However, there is still deficiency of the information concerning not only the occurrence and distribution of antibiotic-resistant bacteria, but also the relationship between antibiotic residues and bacterial resistance, and the influences of mangrove vegetation on the incidence of bacterial resistance in the mangrove area as well. Thus, the objectives of this research are to investigate the occurrence and distribution of antibiotic-resistant bacteria in the mangrove forest and the tidal channel in Gaoqiao mangrove wetland of China, to discuss the potential relationship between the occurrence of resistant bacteria and the antibiotic residues in mangrove area, as well as to elucidate the incidence of bacterial resistance and associated effect of vegetation in mangrove wetland.

\section{Materials and Methods}

\section{Sampling area and sites}

Sampling was conducted in Gaoqiao mangrove area at some established sites (Figure 1). The total area of Gaoqiao Mangrove National Nature Reserve, one of main coastal mangrove forests in China, is $1202 \mathrm{hm}^{2}$, including mangrove vegetation area of 934 $\mathrm{hm}^{2}$ [18]. South-subtropical monsoon climate is prevalent in this area, with an annual average temperature of $22.3{ }^{\circ} \mathrm{C}$ and annual average rainfall of $1500 \mathrm{~mm}$. Seasonal rainfall and most precipitation occur during the summer rainy season or monsoon. The inter-tidal zone is characterized by an irregular diurnal tide per day, and the tidal range is approximately $2 \mathrm{~m}$ [19]. This mangrove area with clay sediments and complex tidal channels offers good conditions for mangrove plants and other marine organisms [20]. Importantly, there are many fish/shrimp ponds around mangrove forests (Figure 1).

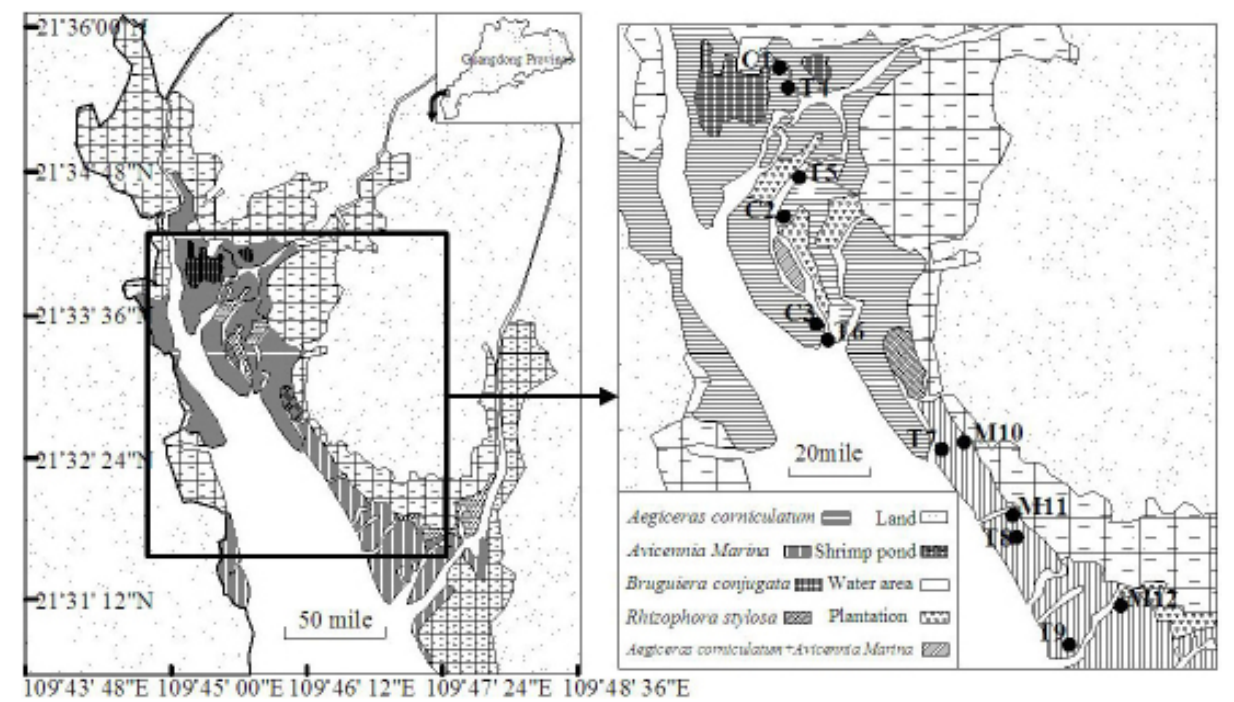

Figure 1: Sampling area and location of sites 
Sampling was performed from 6 different sites in this mangrove forest, where both Aegiceras corniculatum and Avicennia marina are single and dominant species that form respective mangrove assemblages, and from 6 sites in a tidal channel in April, May and June, 2012. Mangrove forests are segregated by many small tidal channels in turn. Characteristic parameters of the mangrove assemblages in sampling sites including average tree height $(\mathrm{m})$, average coverage of canopy, base coverage (\%), average stem height under branch $(\mathrm{m})$ and mean density (ind. $/ \mathrm{m}^{2}$ ) were $4.83,3.59,5.02,0.33,0.56$ and 0.12 in the Aegiceras corniculatum assemblage; and 1.57, 1.11, 1.03, 0.55, 0.48 and 1.10 in the Avicennia marina assemblage, respectively [21]. In April, 2012, 12 sediment samples were taken from the first three sites (marked $\mathrm{C}_{1}, \mathrm{C}_{2}$, and $\mathrm{C}_{3}$ ) in the Aegiceras corniculatum assemblage; In May, 2012, 6 water samples and 6 sediment samples were collected from the tidal channels (marked $\mathrm{T}_{4}, \mathrm{~T}_{5}, \mathrm{~T}_{6}, \mathrm{~T}_{7}, \mathrm{~T}_{8}$, and $\mathrm{T}_{9}$ of water samples, $\mathrm{T}_{4}, \mathrm{~T}_{5}, \mathrm{~T}_{6}, \mathrm{~T}_{7}, \mathrm{~T}_{8}{ }_{8}$, and $\mathrm{T}_{9}$ of sediment samples), The distance of sites between $\mathrm{T}_{4}$ and $\mathrm{T}_{9}$ was approximately 5.12 miles, and the sites in the tidal channel were assigned along the direction from landward to the seaward, in which $\mathrm{T}_{4}$ and $\mathrm{T}_{5}$ were in high inter-tidal zone, $\mathrm{T}_{6}$ and $\mathrm{T}_{7}$ were in middle inter-tidal zone, and $\mathrm{T}_{8}$ and $\mathrm{T}_{9}$ were in low inter-tidal zone approximately. In June, 2012, 12 sediment samples were taken from the last three sites (marked $\mathrm{M}_{10}, \mathrm{M}_{11}$, and $\mathrm{M}_{12}$ ) in the Avicennia marina assemblage. The sequence numbers and sample names were illustrated in Table 1 In the next context, $\mathrm{T}^{\prime}-\mathrm{H}^{\prime}$ (The sum of $\mathrm{T}_{4}{ }_{-}-\mathrm{H}$ and $\mathrm{T}_{5}{ }_{5}-\mathrm{H}$ ), T'-M (The sum of $\mathrm{T}_{6}{ }_{6}-\mathrm{M}$ and $\mathrm{T}_{7}{ }^{-}-\mathrm{M}$ ), T'-L (The sum of $\mathrm{T}_{6}{ }_{6}-\mathrm{M}$ and $\mathrm{T}_{7}{ }_{7}-\mathrm{M}$ ) represent the drug-resistant percentages of antibiotic resistance in bacteria isolated from sediment samples in high, middle and low tidal channel, respectively. The meaning of T-H, T-M and T-L is similar as this in water samples.

\begin{tabular}{|c|c|c|c|c|c|c|c|c|c|c|c|}
\hline \multicolumn{9}{|c|}{ Sediment sample name } & \multicolumn{3}{|c|}{ Water sample name } \\
\hline No. & \multicolumn{2}{|c|}{ Name } & No. & \multicolumn{2}{|c|}{ Name } & No. & \multicolumn{2}{|c|}{ Name } & No. & \multicolumn{2}{|c|}{ Name } \\
\hline 1 & $\mathrm{C}_{1}-\mathrm{H}-\mathrm{B}_{(\mathrm{s})}$ & \multirow{4}{*}{$\mathrm{C}_{1}$} & 13 & $\mathrm{~T}_{4}^{\prime}-\mathrm{H}$ & $\mathrm{T}_{4}^{\prime}$ & 19 & $\mathrm{M}-\mathrm{H}-\mathrm{B}_{(\mathrm{s})}$ & \multirow{4}{*}{$\mathrm{M}_{10}$} & 31 & $\mathrm{~T}_{4}-\mathrm{H}$ & $\mathrm{T}_{4}$ \\
\hline 2 & $\mathrm{C}_{1}-\mathrm{H}-\mathrm{B}_{(\mathrm{B})}$ & & 14 & $\mathrm{~T}_{5}^{\prime}-\mathrm{H}$ & $\mathrm{T}_{5}$ & 20 & $\mathrm{M}-\mathrm{H}-\mathrm{B}_{(\mathrm{B})}$ & & 32 & $\mathrm{~T}_{5}-\mathrm{H}$ & $\mathrm{T}_{5}$ \\
\hline 3 & $\mathrm{C}_{1}-\mathrm{H}-\mathrm{M}_{(\mathrm{S})}$ & & 15 & $\mathrm{~T}_{6}{ }_{6}-\mathrm{M}$ & $\mathrm{T}_{6}$ & 21 & $\mathrm{M}-\mathrm{H}-\mathrm{M}_{(\mathrm{S})}$ & & 33 & $\mathrm{~T}_{6}-\mathrm{M}$ & $\mathrm{T}_{6}$ \\
\hline 4 & $\mathrm{C}_{1}-\mathrm{H}-\mathrm{M}_{(\mathrm{B})}$ & & 16 & $\mathrm{~T}_{7}{ }_{7}-\mathrm{M}$ & $\mathrm{T}_{7}$ & 22 & $\mathrm{M}-\mathrm{H}-\mathrm{M}_{(\mathrm{B})}$ & & 34 & $\mathrm{~T}_{7}-\mathrm{M}$ & $\mathrm{T}_{7}$ \\
\hline 5 & $\mathrm{C}_{2}-\mathrm{M}-\mathrm{B}_{(\mathrm{S})}$ & \multirow{4}{*}{$\mathrm{C}_{2}$} & 17 & $\mathrm{~T}_{8}^{\prime}-\mathrm{L}$ & $\mathrm{T}_{8}^{\prime}$ & 23 & $\mathrm{M}-\mathrm{M}-\mathrm{B}_{(\mathrm{s})}$ & \multirow{4}{*}{$\mathrm{M}_{11}$} & 35 & $\mathrm{~T}_{8}-\mathrm{L}$ & $\mathrm{T}_{8}$ \\
\hline 6 & $\mathrm{C}_{2}-\mathrm{M}-\mathrm{B}_{(\mathrm{B})}$ & & 18 & $\mathrm{~T}_{9}^{\prime \prime}-\mathrm{L}$ & $\mathrm{T}_{9}$ & 24 & $\mathrm{M}-\mathrm{M}-\mathrm{B}_{(\mathrm{B})}$ & & 36 & $\mathrm{~T}_{9}-\mathrm{L}$ & $\mathrm{T}_{9}$ \\
\hline 7 & $\mathrm{C}_{2}-\mathrm{M}-\mathrm{M}_{(\mathrm{S})}$ & & & & & 25 & $\mathrm{M}-\mathrm{M}-\mathrm{M}_{(\mathrm{S})}$ & & & & \\
\hline 8 & $\mathrm{C}_{2}-\mathrm{M}-\mathrm{M}_{(\mathrm{B})}$ & & & & & 26 & $\mathrm{M}-\mathrm{M}-\mathrm{M}_{(\mathrm{B})}$ & & & & \\
\hline 9 & $\mathrm{C}_{3}-\mathrm{L}-\mathrm{B}_{(\mathrm{S})}$ & \multirow{4}{*}{$\mathrm{C}_{3}$} & & & & 27 & $\mathrm{M}-\mathrm{L}-\mathrm{B}_{(\mathrm{S})}$ & \multirow{4}{*}{$\mathrm{M}_{12}$} & & & \\
\hline 10 & $\mathrm{C}_{3}-\mathrm{L}-\mathrm{B}_{(\mathrm{B})}$ & & & & & 28 & $\mathrm{M}-\mathrm{L}-\mathrm{B}_{(\mathrm{B})}$ & & & & \\
\hline 11 & $\mathrm{C}_{3}-\mathrm{L}-\mathrm{M}_{(\mathrm{S})}$ & & & & & 29 & $\mathrm{M}-\mathrm{L}-\mathrm{M}_{(\mathrm{S})}$ & & & & \\
\hline 12 & $\mathrm{C}_{3}-\mathrm{L}-\mathrm{M}_{(\mathrm{B})}$ & & & & & 30 & $\mathrm{M}-\mathrm{L}-\mathrm{M}_{(\mathrm{B})}$ & & & & \\
\hline
\end{tabular}

* The first alphabet of sample name meant different sample sites (C: Aegiceras corniculatum; T: tidal channel; M: Avicennia marina); the second meant tidal level in the tidal channel (H: high inter-tidal zone; M: middle inter-tidal zone; L: low inter-tidal zone), whereas, in the mangrove area that meant tidal flat level (H: high tidal flat; $\mathrm{M}$ : middle tidal flat; L: low tidal flat), and the third meant whether there were mangrove vegetation in sampling sites (B: bare mudflat; M: mangrove forest). S and B in parenthesis were representing surface layer and bottom layer sediment, respectively

Table 1: The sample number and name of water and sediments*

\section{Sample collection}

A total of 36 study samples ( 6 water samples and 30 sediment samples) were collected in this investigation. The sampling in mangrove forests were divided into two transects ( 3 surface sediments and 3 bottom sediments) in both Aegiceras corniculatum assemblage and Avicennia marina assemblage, including the corresponding bare mudflats without any vegetation. In each mangrove assemblage and corresponding bare mudflat, three sampling quadrats were set up along two parallel transects respectively. The high and low sampling quadrats (namely the high and low tidal flat) were also established at a distance of 30 meters into each mangrove stand from the mangrove canopy edge, with the mid sampling quadrats (namely the mid tidal flat) halfway between the two. Sediment samples were separately collected from two parallel quadrats. The samples consisted of four different plots at intervals of 20 meters and were mixed into a homogeneous sample respectively, so a total of twenty-four sediment samples were taken in both mangrove assemblages and corresponding bare mudflats. In addition, 12 samples (6 water samples and 6 surface sediment samples) were collected in tidal channels, which were set up at different inter-tidal levels (i.e. high, mid and low intertidal zones) along the tidal gradient.

Water samples in the tidal channel were collected on a fishing boat using $2 \mathrm{~L}$ sterile polyethylene bottles at high tide, and sediment samples (approximately $500 \mathrm{~g}$ for each one) collected using a Teflon corer at low tide were divided into two layers: $0-5 \mathrm{~cm}$ (surface layer) and $15-25 \mathrm{~cm}$ (bottom layer) in reference to the advocating method in both mangrove assemblages and corresponding bare mudflats, while only surface sediment $(0-5 \mathrm{~cm})$ samples were taken in tidal channel [22]. All of the collected samples were placed into sterile glass boxes, and then immediately transported from the sampling sites to the laboratory in an ice cooler. Samples were processed for bacterial isolation and antibiotic sensitivity tests. 


\section{Isolation of bacteria}

Bacteria from water and sediment sample were isolated using the spread plate technique [23]. 1g of mixed sediment sample or $1 \mathrm{~mL}$ of mixed water sample was homogenized in $10 \mathrm{~mL}$ of sterilized seawater. The homogenized sample was diluted with autoclaved seawater and serial 10 -fold dilution up to $10^{4}$. A fixed amount of $100 \mu \mathrm{L}$ of each dilution was spread onto the Zobell $2216 \mathrm{E}$ agar medium in duplicate. Then, the plated samples were incubated at $28{ }^{\circ} \mathrm{C}$ for $36 \mathrm{~h}$. After incubation, the representative colonies (approximate 30 bacterial colonies for each sample) were chosen at random from plates and purified on Zobell 2216E slant agar medium for further studies of antibiotic resistance [14].

\section{Antibiotic sensitivity test}

Antibiotic resistance of bacteria was tested according to the single disc-diffusion method described by the National Committee for Clinical Laboratory Standards (NCCLS) with the Mueller-Hinton Agar (Beijing Luqiao Technology Co., Ltd). All antibiotic sensitivity tests took standard strains Escherichia coli ATCC 25922 and Staphylococcus aureus ATCC 29213 as controls for the disk diffusion technique to measure the inhibition zone. After single isolate recovered for $24 \mathrm{~h}$ at normal temperature respectively, isolates were inoculated in Muller-Hinton Broth and incubated for the appropriate time [14]. The turbidity of the bacterial suspension was compared with \#5 MacFarland's Barium Sulfate Standard Solution. When the abundance of the bacteria was approximately equivalent to $1.5 \times 10^{8} \mathrm{cfu} / \mathrm{mL}, 100 \mu \mathrm{L}$ of bacterial suspension was evenly spread on the Muller-Hinton Agar with sterile cotton swabs and left to dry for $10 \mathrm{~min}$ before placing the antibiotic sensitivity discs. The blotting paper discs (Ø6mm, Hangzhou Tianhe Microorganism Co., Ltd) were then placed onto the agar dishes, which were incubated at $4{ }^{\circ} \mathrm{C}$ for $1 \mathrm{~h}$ to allow antibiotic diffusion from the discs into the agar medium. The dishes were then incubated at $28 \pm 1^{\circ} \mathrm{C}$ for $24 \mathrm{~h}$. After incubation, the diameter (in mm) of the areas that illustrated bacterial growth inhibition by the antibiotics was measured. The following 12 antibiotics with their

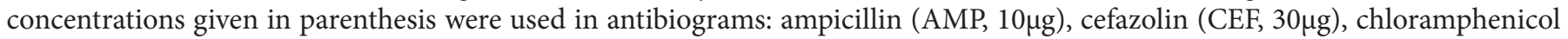

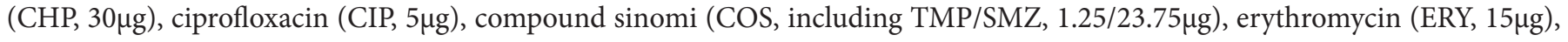

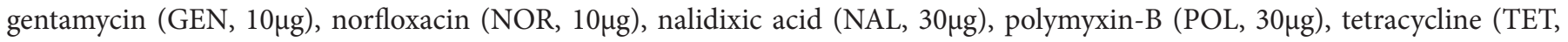
$30 \mu \mathrm{g}$ ), and trimethoprim (TMP, $5 \mu \mathrm{g}$ ). Bacterial resistance to antibiotics was classified according to the manufacturer's instructions and NCCLS.

All tested antibiotics were classified into 8 different categories according to their chemical structure: $\beta$-lactams (ampicillin, cefazolin), Aminoglycosides (gentamycin), Macrolides (erythromycin), Quinolones (ciprofloxacin, norfloxacin, nalidixic acid), Sulfonamides (Compound sinomi, trimethoprim), Chloramphenicols (chloramphenicol), Polymyxins (polymyxin-B), Tetracyclines (tetracycline).

\section{Data treatment and statistical analysis}

The percentage of antibiotic resistance in bacteria was given as the fraction of number of antibiotic-resistant bacteria compared to the total number of colonies obtained from samples (water and sediment) [15]. The Multiple Antibiotic Resistance (MAR) for bacteria was calculated according to Webster, et al. [24]. MAR index=No. of antibiotics to which the isolate was number of resistant antibiotics/total number of antibiotics exposed (NO. $\geq 3$ ).

Statistical analyses in this study were carried out with SPSS (Statistic Package for the Social Science) software for windows (Version 21). One-way Analysis of Variance (ANOVA, Games-Howell) was used to test the differences in the antibiotic resistance among the bacteria isolated from the samples (sediment and water samples) in different tidal channels, and from different layer sediment, as well as among those toward to different antibiotic agents. Likewise, this method was also employed to examine the differences in the antibiotic resistance between mangrove assemblages and the corresponding bare mudflats, and in MAR of antibiotic-resistant bacteria isolated from samples (water and sediment) among 3 tidal channels. The paired-samples T-test was applied to analyze the differences in antibiotic resistance of bacteria between Aegiceras corniculatum assemblage and Avicennia marina assemblage. The relationship of bacterial resistance to antibiotics between surface and bottom sediment in mangrove forests was evaluated with Pearson correlation.

\section{Results}

The distribution of antibiotic-resistant bacteria in the tidal channel

\section{Water samples}

Bacterial resistance to 12 antibiotics was estimated in a total of 133 bacterial isolates from 6 water samples in high, middle and low tidal channel. It is indicated that all bacterial strains were extremely sensitive to POL (Figure 2). In addition, bacterial resistances to AMP (T-H: 29.17\%, T-M: 32.61\%, T-L: 66.18\%), CEF (T-H: 20.84\%, T-M: 30.44\%, T-L: 66.18\%), TMP (T-H: 29.17\%, T-M: 36.96\%, T-L: $54.41 \%$ ), and COS (T-H: $12.50 \%$, T-M: $26.09 \%$, T-L: $53.75 \%)$ were significantly higher than to other antibiotics in all tidal channels (ANOVA, $p<0.05$ ). Bacteria isolated from the water were more resistant to the tested antibiotics (AMP, CEF, COS, ERY and TMP) in the low tidal channel than in the others. However, Games-Howell analysis showed that no significant differences in bacterial resistance to all antibiotics were observed among 3 tidal channels (ANOVA, $p>0.05$ ). Moreover, the quinolone-resistant 
bacteria were found in all tidal channels. In low tidal channel, bacterial strains revealed resistant to NAL and CIP with percentages of $2.94 \%$ and $2.28 \%$ in turn, simultaneously, the bacteria isolated from middle and high tidal channel showed resistance to NOR $(2.18 \%)$ and NAL (4.17\%) respectively although their percentages were somewhat lower (Figure 2).

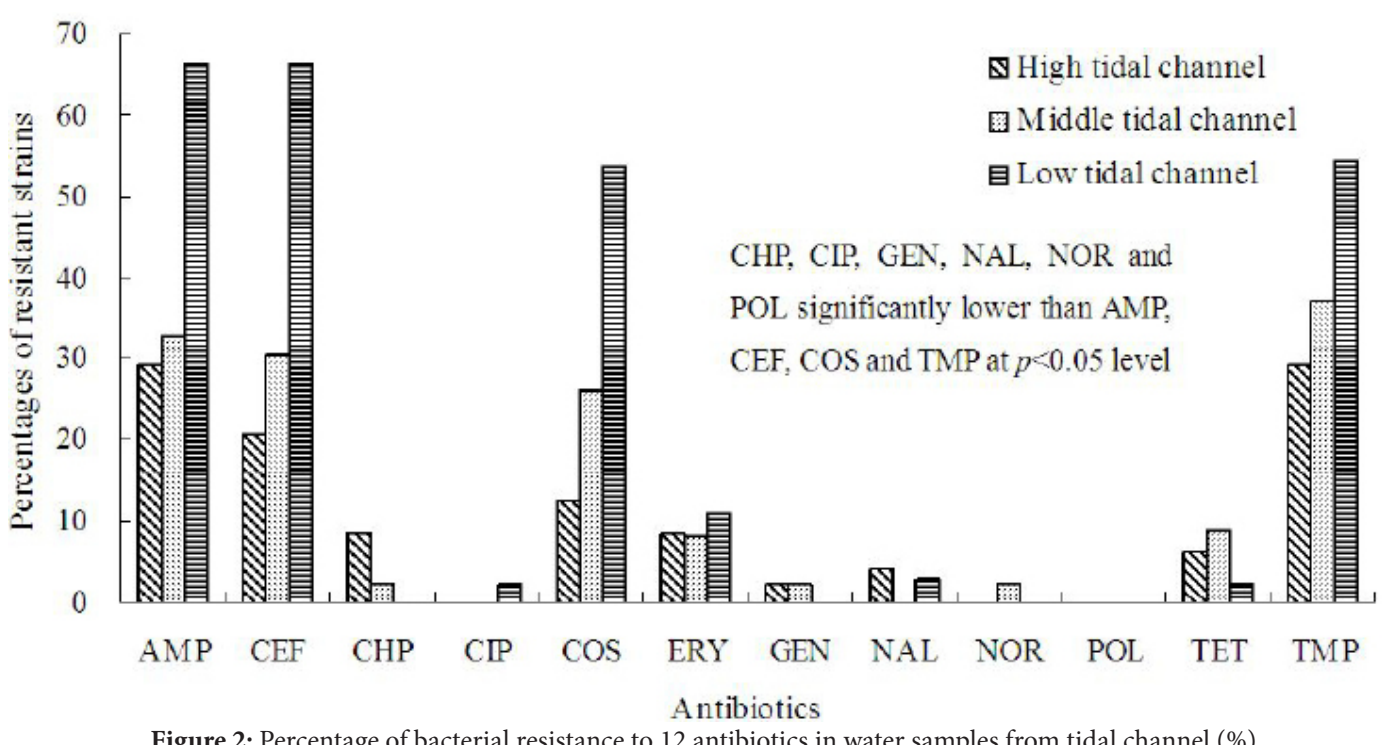

\section{Sediment samples}

A total of 143 isolates from 6 sediment samples in the tidal channel were collected to investigate bacterial resistance to antibiotics (Figure 3). The investigational results exhibited that the antibiotic-resistant profile of bacteria isolated from these sediment samples is similar as that from water samples. The percentages of antibiotic resistance to AMP (T'-M: 36.23\%, T'-L: 39.34\%), CEF (T'-M: 27.63\%, T'-L: 37.25\%), TMP (T'-M: 29.71\%, T'-L: 34.50\%), COS (T'-M: 18.12\%, T'-L: 30.00\%) in bacteria were significantly higher than those to remaining antibiotics in low and middle tidal channel (ANOVA, $p<0.05$ ). However, the bacterial resistances to CHP, NAL and TET were relatively higher in high tidal channel, with corresponding percentages of $18.00 \%, 6.26 \%$ and $15.17 \%$ in turn. Similar pattern was also discovered in the sediments where the percentage of bacterial resistance to the tested antibiotics (AMP, CEF, COS, ERY and TMP) were slightly higher than to other antibiotics in low tidal channel. Similarly, no significant differences were found in bacterial resistance among 3 tidal channels (ANOVA, $p>0.05$ ), and quinolone-resistant bacteria were detected in all tidal channels.

The distribution of antibiotic-resistant bacteria in the mangrove forests.

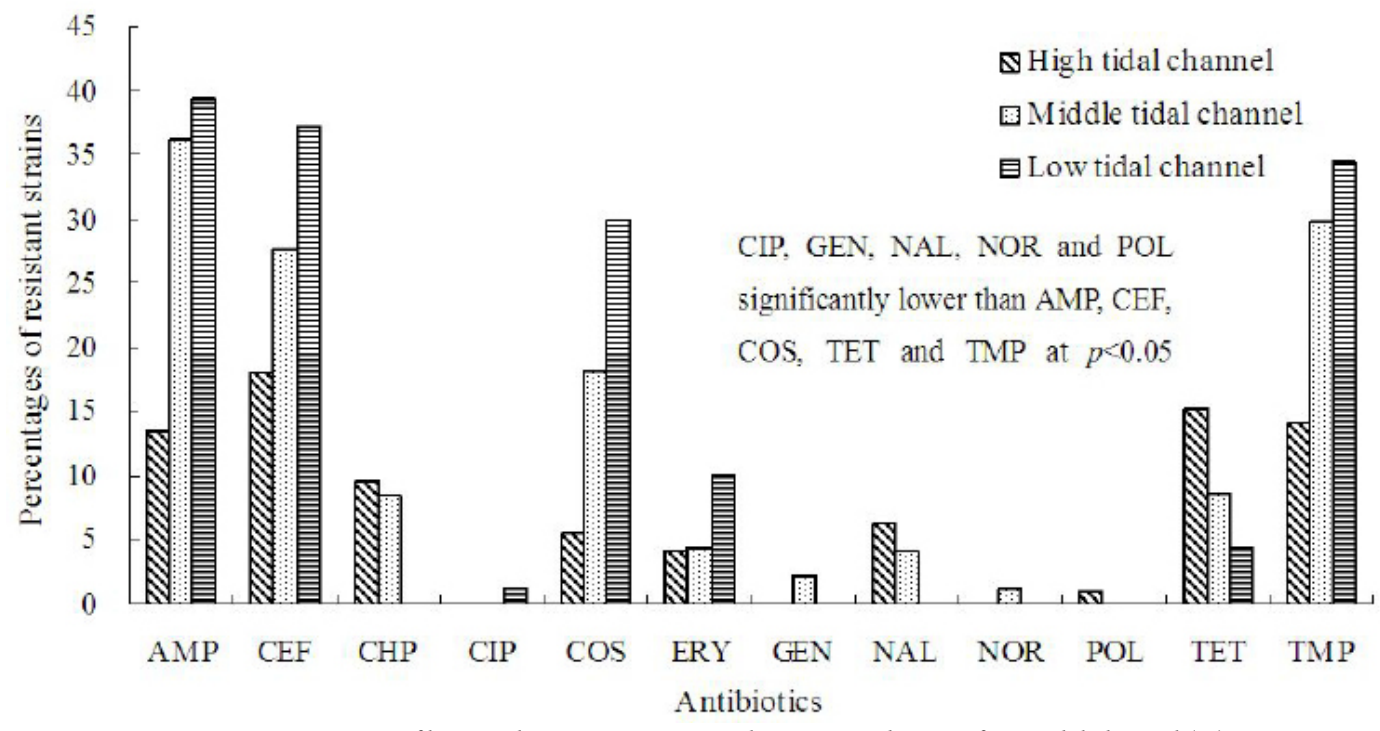

Figure 3: Percentage of bacterial resistance to 12 antibiotics in sediments from tidal channel (\%)

Aegiceras corniculatum assemblage and Avicennia marina assemblage: A total of 287 and 291 colonies from the sediments in Aegiceras corniculatum assemblage and Avicennia marina assemblage, including the corresponding bare mudflats, were respectively isolated to investigate the distribution of antibiotic-resistant bacteria and the influence of different assemblages on the bacterial resistance to antibiotics (Table 2 and 3). All of bacterial strains isolated from the surface sediment were extremely sensitive to CIP, ERY and GEN (Table 2). 


\begin{tabular}{|c|c|c|c|c|c|c|c|}
\hline \multirow{2}{*}{ Antibiotic } & \multicolumn{9}{|c|}{ Aegiceras corniculatum assemblage } & \multicolumn{3}{|c|}{ Avicennia marina assemblage } & \multirow{2}{*}{ Mean \pm SD } \\
\cline { 2 - 7 } & $\mathbf{C}_{\mathbf{1}}$ & $\mathbf{C}_{2}$ & $\mathbf{C}_{\mathbf{3}}$ & $\mathbf{M}_{\mathbf{1 0}}$ & $\mathbf{M}_{11}$ & $\mathbf{M}_{\mathbf{1 2}}$ & \\
\hline AMP & $\mathbf{1 9 . 2 3}$ & 0.00 & $\mathbf{3 9 . 1 3}$ & $\mathbf{1 0 0 . 0 0}$ & $\mathbf{1 0 0 . 0 0}$ & $\mathbf{1 0 0 . 0 0}$ & $\mathbf{5 9 . 7 3 \pm 4 5 . 8 1}$ \\
\hline CEF & $\mathbf{1 5 . 3 8}$ & 0.00 & 4.35 & $\mathbf{9 6 . 0 0}$ & $\mathbf{1 0 0 . 0 0}$ & $\mathbf{9 2 . 0 0}$ & $\mathbf{5 1 . 2 9} \pm \mathbf{4 9 . 3 0 0}$ \\
\hline CHP & $\mathbf{4 2 . 3 1}$ & 4.00 & 0.00 & 8.00 & 0.00 & 0.00 & $9.05 \pm 16.6$ \\
\hline CIP & 0.00 & 0.00 & 0.00 & 0.00 & 0.00 & 0.00 & $0.00 \pm 0.00$ \\
\hline COS & 7.69 & 0.00 & 0.00 & $\mathbf{8 4 . 0 0}$ & $\mathbf{4 8 . 0 0}$ & $\mathbf{5 2 . 0 0}$ & $\mathbf{3 1 . 9 5 \pm 3 4 . 6 4}$ \\
\hline ERY & 0.00 & 0.00 & 0.00 & 0.00 & 0.00 & 0.00 & $0.00 \pm 0.00$ \\
\hline GEN & 0.00 & 0.00 & 0.00 & 0.00 & 0.00 & 0.00 & $0.00 \pm 0.00$ \\
\hline NAL & 0.00 & 0.00 & 8.70 & 0.00 & 0.00 & 0.00 & $1.45 \pm 3.55$ \\
\hline NOR & $\mathbf{0 . 0 0}$ & $\mathbf{1 2 . 0 0}$ & $\mathbf{8 . 7 0}$ & $\mathbf{0 . 0 0}$ & $\mathbf{0 . 0 0}$ & $\mathbf{0 . 0 0}$ & $\mathbf{3 . 4 5} \pm 5.45$ \\
\hline POL & 0.00 & 0.00 & 39.13 & $\mathbf{8 0 . 0 0}$ & 0.00 & $\mathbf{6 8 . 0 0}$ & $\mathbf{3 1 . 1 9} \pm \mathbf{3 6 . 6 6}$ \\
\hline TET & 0.00 & 0.00 & 34.78 & 0.00 & 0.00 & 20.00 & $9.13 \pm 14.90$ \\
\hline TMP & $\mathbf{1 5 . 3 8}$ & $\mathbf{1 6 . 0 0}$ & $\mathbf{3 4 . 7 8}$ & $\mathbf{1 0 0 . 0 0}$ & $\mathbf{1 0 0 . 0 0}$ & $\mathbf{9 2 . 0 0}$ & $\mathbf{5 9 . 6 9 \pm 4 1 . 9 2}$ \\
\hline
\end{tabular}

Table 2: Percentage of bacterial resistance to 12 antibiotics in the surface sediments of Aegiceras corniculatum assemblage and Avicennia marina assemblage (\%)

\begin{tabular}{|c|c|c|c|c|c|c|c|}
\hline \multirow{2}{*}{ Antibiotic } & \multicolumn{3}{|c|}{ Aegiceras corniculatum assemblage } & \multicolumn{3}{|c|}{ Avicennia marina assemblage } & \multirow{2}{*}{$\operatorname{Mean} \pm$ SD } \\
\hline & $\mathrm{C}_{1}$ & $\mathrm{C}_{2}$ & $\mathrm{C}_{3}$ & $M_{10}$ & $M_{11}$ & $M_{12}$ & \\
\hline AMP & 0.00 & 27.27 & 8.00 & 80.00 & 100.00 & 100.00 & $52.55 \pm 46.13$ \\
\hline CEF & 0.00 & 0.00 & 4.00 & 52.00 & 84.00 & 96.00 & $39.33 \pm 44.07$ \\
\hline $\mathrm{CHP}$ & 0.00 & 0.00 & 0.00 & 8.00 & 0.00 & 0.00 & $1.33 \pm 3.27$ \\
\hline CIP & 0.00 & 4.55 & 0.00 & 0.00 & 0.00 & 0.00 & $0.76 \pm 1.86$ \\
\hline COS & 0.00 & 9.09 & 8.00 & 84.00 & 84.00 & 100.00 & $47.52 \pm 46.29$ \\
\hline ERY & 0.00 & 4.55 & 4.00 & 4.00 & 0.00 & 0.00 & $2.09 \pm 2.30$ \\
\hline GEN & 0.00 & 0.00 & 0.00 & 0.00 & 0.00 & 0.00 & $0.00 \pm 0.00$ \\
\hline NAL & 0.00 & 0.00 & 0.00 & 0.00 & 4.00 & 0.00 & $0.67 \pm 1.63$ \\
\hline NOR & 0.00 & 0.00 & 4.00 & 0.00 & 0.00 & 0.00 & $0.67 \pm 1.63$ \\
\hline POL & 0.00 & 18.18 & 0.00 & 0.00 & 4.00 & 36.00 & $9.70 \pm 14.69$ \\
\hline TET & 0.00 & 18.18 & 0.00 & 16.00 & 56.00 & 0.00 & $15.03 \pm 21.76$ \\
\hline TMP & 0.00 & 22.73 & 0.00 & 92.00 & 96.00 & 100.00 & $51.79 \pm 49.20$ \\
\hline
\end{tabular}

Table 3: Percentage of bacterial resistance to 12 antibiotics in the bottom sediments of Aegiceras corniculatum assemblage and Avicennia marina assemblage (\%)

Furthermore, the percentages of bacterial resistance to AMP, CEF, COS and TMP from 3 tidal flats were over $40 \%$ in the Avicennia marina assemblage, while antibiotic resistance only to CHP in bacteria isolated from high tidal flats $\left(C_{1}\right)$ was above $40 \%$ in the Aegiceras corniculatum assemblage. Interestingly, quinolone-resistant bacteria screened from the surface sediment was present in Aegiceras corniculatum assemblage but not in the Avicennia marina assemblage. In general, the antibiotic resistance of bacteria isolated from the surface sediments was significantly higher in Avicennia marina assemblage than in Aegiceras corniculatum assemblage (T-test, $p<0.05)$.

Differently, the bacteria screened from all of bottom sediments were only sensitive to GEN, and no resistant bacteria were found in $\mathrm{C}_{1}$ (Table 3). The bacteria isolated from the bottom sediments in Aegiceras corniculatum assemblage displayed the highest percentage of antibiotic resistance to AMP (27.27\%), followed by to TMP (22.73\%), POL (18.18\%) and TET (18.18\%) successively. Antibiotic-resistant bacteria screened from the bottom sediments in Avicennia marina assemblage exhibited simultaneously higher resistances to AMP, CEF, COS and TMP, with percentage of more than $50 \%$ for all of them. Antibiotic resistance of bacteria was significantly stronger in Avicennia marina assemblage than in Aegiceras corniculatum assemblage (T-test, $p<0.05$ ). In comparison to samples in the surface sediments, the quinolone-resistant bacteria inhabited in the bottom sediments were found not only in the Aegiceras corniculatum assemblage, but also in the Avicennia marina assemblage.

Bacteria isolated from bottom and surface sediments in both mangrove assemblages were characterized by differences in the antibiotic resistance (Figure 4). In this study, we found bacteria isolated from the bottom sediment were more resistant to some tested antibiotics (AMP, CEF, COS, TET and TMP) than bacteria isolated from the surface one, although no significant differences in the antibiotic resistance of bacteria were able to be revealed between bottom and surface sediments in both mangrove assemblages (ANOVA, $p=0.382>0.05$ ). In addition, Pearson correlation analysis indicated that the antibiotic resistance of bacteria from the bottom sediments showed a significant positive correlation with that from the surface sediments $(\mathrm{r}=0.923, p<0.05)$ in both mangrove assemblages. 


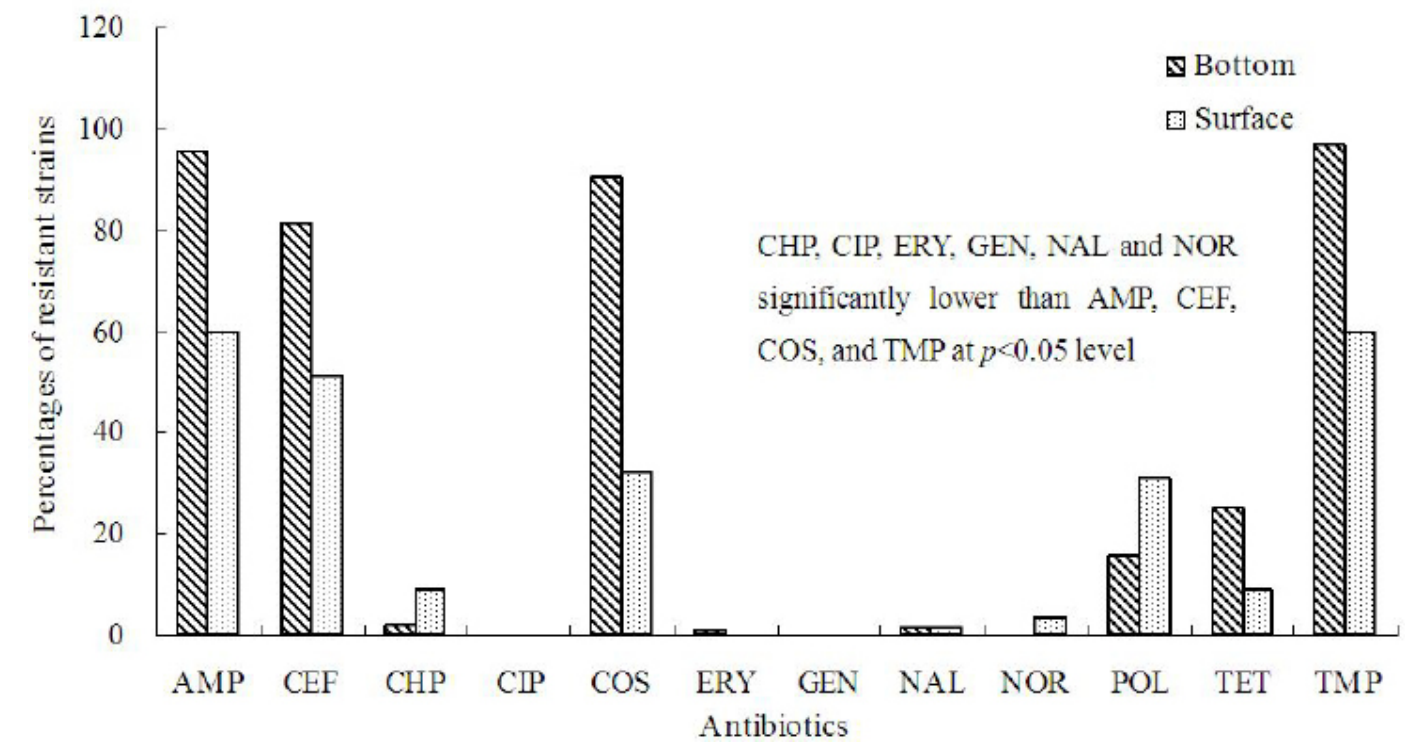

Figure 4: Percentage of bacterial resistance to 12 antibiotics in the surface and bottom sediments in both mangrove assemblages (\%)

Mangrove assemblages and the corresponding bare mudflats: Differences in the antibiotic resistance of bacteria were determined between the mangrove assemblages and the corresponding bare mudflats (Figure 5). Tested bacterial strains isolated from sediment samples in both mangrove assemblages and the corresponding bare mudflats showed the highest percentage of antibiotic resistance to AMP (59.73\%) and TMP (40.77\%), respectively. Meanwhile, the bacterial resistance to 6 antibiotics, namely AMP, CEF, COS, NOR, POL and TMP, was higher in the mangrove assemblages than in the corresponding bare mudflats. However, no significant differences in bacterial resistance to 12 antibiotics were found between mangrove assemblages and the corresponding bare mudflats (ANOVA, $p>0.05$ ).

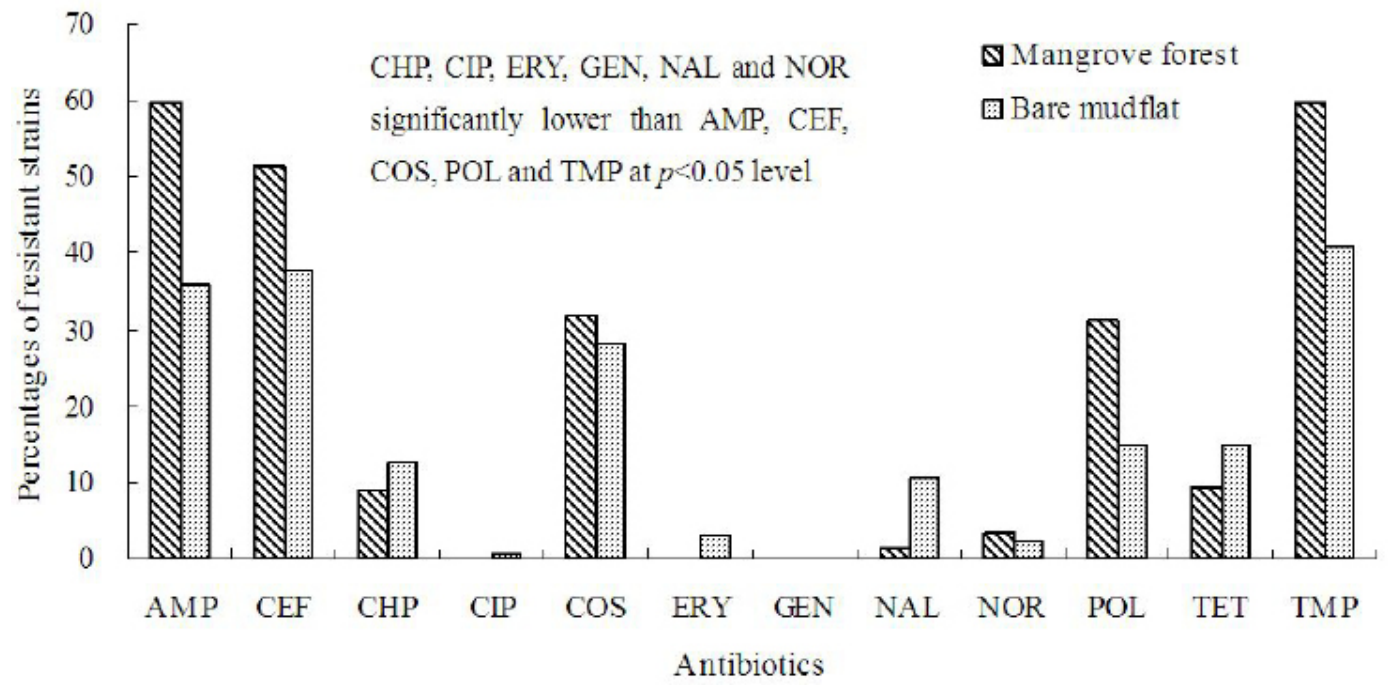

Figure 5: Percentage of bacterial resistance to 12 antibiotics in the mangrove assemblages and corresponding bare mudflats (\%)

\section{Multiple antibiotic resistance}

Multiple antibiotic resistance (MAR) of some bacterial strains cannot be ignored in this mangrove area (Table 4). In tidal channel, the bacteria isolated from all sampling sites showed MAR, of which the bacteria at $\mathrm{T}_{4}$ and $\mathrm{T}_{7}$ has MAR to 9 and 8 antibiotics in water samples, respectively. In general, the bacteria isolated from sediment and water samples in tidal channel possessed MAR to 3-4 antibiotics. Similarly, the bacteria isolated from the sediment in Aegiceras corniculatum assemblage showed MAR to 3-4 antibiotics, while those in Avicennia marina assemblage exhibited MAR to 3-5 antibiotics. Tested bacterial strains isolated from

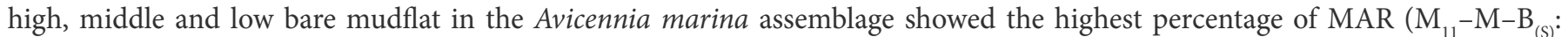
$81.71 \%, \mathrm{M}_{12}-\mathrm{L}-\mathrm{B}_{(\mathrm{S})}: 63.61 \%$, and $\mathrm{M}_{10}-\mathrm{H}-\mathrm{B}_{(\mathrm{S})}: 63.27 \%$, respectively). Our results imply that MAR of bacteria was more deteriorated in Avicennia marina assemblage than in Aegiceras corniculatum assemblage, in spite of the fact that no significant differences in MAR of bacteria isolated from samples (water and sediment) can be found among 3 tidal channels $(p>0.05)$. 


\begin{tabular}{|c|c|c|c|c|c|c|c|c|c|}
\hline \multirow{2}{*}{ Site } & \multirow{2}{*}{ Sample } & \multicolumn{7}{|c|}{ Resistance to $\mathrm{n}$ antibiotics (\% of isolates) } & \multirow{2}{*}{ Sum } \\
\hline & & 3 & 4 & 5 & 6 & 7 & 8 & 9 & \\
\hline \multirow{4}{*}{$\mathrm{C}_{1}$} & $\mathrm{C}_{1}-\mathrm{H}-\mathrm{B}_{(\mathrm{s})}$ & 3.85 & 7.69 & 0.00 & 0.00 & 0.00 & 0.00 & 0.00 & 11.54 \\
\hline & $\mathrm{C}_{1}-\mathrm{H}-\mathrm{B}_{(\mathrm{B})}$ & 0.00 & 0.00 & 0.00 & 0.00 & 0.00 & 0.00 & 0.00 & 0.00 \\
\hline & $\mathrm{C}_{1}-\mathrm{H}-\mathrm{M}_{(\mathrm{S})}$ & 4.35 & 0.00 & 0.00 & 0.00 & 0.00 & 0.00 & 0.00 & 4.35 \\
\hline & $\mathrm{C}_{1}-\mathrm{H}-\mathrm{M}_{(\mathrm{B})}$ & 0.00 & 0.00 & 0.00 & 0.00 & 0.00 & 0.00 & 0.00 & 0.00 \\
\hline \multirow{4}{*}{$\mathrm{C}_{2}$} & $\mathrm{C}_{2}-\mathrm{M}-\mathrm{B}_{(\mathrm{S})}$ & 0.00 & 0.00 & 0.00 & 0.00 & 0.00 & 0.00 & 0.00 & 0.00 \\
\hline & $\mathrm{C}_{2}-\mathrm{M}-\mathrm{B}_{(\mathrm{B})}$ & 0.00 & 9.09 & 4.55 & 0.00 & 4.55 & 0.00 & 0.00 & 18.18 \\
\hline & $\mathrm{C}_{2}-\mathrm{M}-\mathrm{M}_{(\mathrm{S})}$ & 13.64 & 40.91 & 4.55 & 0.00 & 0.00 & 0.00 & 0.00 & 59.09 \\
\hline & $\mathrm{C}_{2}-\mathrm{M}-\mathrm{M}_{(\mathrm{B})}$ & 0.00 & 0.00 & 0.00 & 0.00 & 0.00 & 0.00 & 0.00 & 0.00 \\
\hline \multirow{4}{*}{$\mathrm{C}_{3}$} & $\mathrm{C}_{3}-\mathrm{L}-\mathrm{B}_{(\mathrm{S})}$ & 4.35 & 30.43 & 0.00 & 0.00 & 0.00 & 0.00 & 0.00 & 34.78 \\
\hline & $\mathrm{C}_{3}-\mathrm{L}-\mathrm{B}_{(\mathrm{B})}$ & 0.00 & 0.00 & 0.00 & 0.00 & 0.00 & 0.00 & 0.00 & 0.00 \\
\hline & $\mathrm{C}_{3}-\mathrm{L}-\mathrm{M}_{(\mathrm{S})}$ & 0.00 & 0.00 & 0.00 & 0.00 & 0.00 & 0.00 & 0.00 & 0.00 \\
\hline & $\mathrm{C}_{3}-\mathrm{L}-\mathrm{M}_{(\mathrm{B})}$ & 0.00 & 0.00 & 0.00 & 0.00 & 0.00 & 0.00 & 0.00 & 0.00 \\
\hline \multirow{2}{*}{$\mathrm{T}_{4}$} & $\mathrm{~T}_{4}^{\prime}-\mathrm{H}$ & 0.00 & 4.35 & 8.70 & 0.00 & 0.00 & 0.00 & 0.00 & 13.04 \\
\hline & $\mathrm{T}_{4}-\mathrm{H}$ & 25.00 & 12.50 & 4.17 & 0.00 & 0.00 & 0.00 & 4.17 & 45.83 \\
\hline \multirow{2}{*}{$\mathrm{T}_{5}$} & $\mathrm{~T}_{5}^{\prime}-\mathrm{H}$ & 4.00 & 0.00 & 0.00 & 0.00 & 0.00 & 0.00 & 0.00 & 4.00 \\
\hline & $\mathrm{T}_{5}-\mathrm{H}$ & 27.60 & 6.54 & 0.00 & 0.00 & 0.00 & 0.00 & 0.00 & 34.14 \\
\hline \multirow{2}{*}{$\mathrm{T}_{6}$} & $\mathrm{~T}_{6}^{\prime}-\mathrm{M}$ & 8.70 & 4.35 & 0.00 & 0.00 & 0.00 & 0.00 & 0.00 & 13.04 \\
\hline & $\mathrm{T}_{6}-\mathrm{M}$ & 4.35 & 8.70 & 8.70 & 0.00 & 0.00 & 0.00 & 0.00 & 21.74 \\
\hline \multirow{2}{*}{$\mathrm{T}_{7}$} & $\mathrm{~T}_{7}^{\prime}-\mathrm{M}$ & 9.52 & 4.76 & 0.00 & 0.00 & 0.00 & 0.00 & 0.00 & 14.29 \\
\hline & $\mathrm{T}_{7}-\mathrm{M}$ & 0.00 & 34.78 & 0.00 & 0.00 & 0.00 & 4.35 & 0.00 & 39.13 \\
\hline \multirow{2}{*}{$\mathrm{T}_{8}$} & $\mathrm{~T}_{8}^{\prime}-\mathrm{L}$ & 8.33 & 0.00 & 0.00 & 0.00 & 0.00 & 0.00 & 0.00 & 8.33 \\
\hline & $\mathrm{T}_{8}-\mathrm{L}$ & 0.00 & 50.00 & 0.00 & 0.00 & 0.00 & 0.00 & 0.00 & 50.00 \\
\hline \multirow{2}{*}{$\mathrm{T}_{9}$} & $\mathrm{~T}_{9}{ }_{9}-\mathrm{L}$ & 4.17 & 8.33 & 0.00 & 0.00 & 0.00 & 0.00 & 0.00 & 12.50 \\
\hline & $\mathrm{T}_{9}-\mathrm{L}$ & 5.88 & 41.18 & 5.88 & 0.00 & 0.00 & 0.00 & 0.00 & 52.94 \\
\hline \multirow{4}{*}{$\mathrm{M}_{10}$} & $\mathrm{M}_{10}-\mathrm{H}-\mathrm{B}_{(\mathrm{s})}$ & 0.00 & 21.67 & 33.60 & 8.00 & 0.00 & 0.00 & 0.00 & 63.27 \\
\hline & $\mathrm{M}_{10}-\mathrm{H}-\mathrm{B}_{(\mathrm{B})}$ & 20.47 & 0.00 & 14.48 & 0.00 & 0.00 & 0.00 & 0.00 & 34.95 \\
\hline & $\mathrm{M}_{10}-\mathrm{H}-\mathrm{M}_{(\mathrm{S})}$ & 4.85 & 24.20 & 21.63 & 4.34 & 0.00 & 0.00 & 0.00 & 55.02 \\
\hline & $\mathrm{M}_{10}-\mathrm{H}-\mathrm{M}_{(\mathrm{B})}$ & 0.00 & 55.29 & 0.00 & 0.00 & 0.00 & 0.00 & 0.00 & 55.29 \\
\hline \multirow{4}{*}{$\mathrm{M}_{11}$} & $\mathrm{M}_{11}-\mathrm{M}-\mathrm{B}_{(\mathrm{s})}$ & 52.84 & 28.87 & 0.00 & 0.00 & 0.00 & 0.00 & 0.00 & 81.71 \\
\hline & $\mathrm{M}_{11}-\mathrm{M}-\mathrm{B}_{(\mathrm{B})}$ & 20.00 & 0.00 & 21.60 & 4.00 & 0.00 & 0.00 & 0.00 & 45.60 \\
\hline & $\mathrm{M}_{11}-\mathrm{M}-\mathrm{M}_{(\mathrm{S})}$ & 0.00 & 25.78 & 0.00 & 12.56 & 0.00 & 0.00 & 0.00 & 38.34 \\
\hline & $\mathrm{M}_{11}-\mathrm{M}-\mathrm{M}_{(\mathrm{B})}$ & 0.00 & 40.36 & 14.29 & 0.00 & 0.00 & 0.00 & 0.00 & 54.65 \\
\hline \multirow{4}{*}{$M_{12}$} & $\mathrm{M}_{12}-\mathrm{L}-\mathrm{B}_{(\mathrm{s})}$ & 12.34 & 24.00 & 19.27 & 8.00 & 0.00 & 0.00 & 0.00 & 63.61 \\
\hline & $\mathrm{M}_{12}-\mathrm{L}-\mathrm{B}_{(\mathrm{B})}$ & 4.00 & 36.70 & 21.60 & 0.00 & 0.00 & 0.00 & 0.00 & 62.30 \\
\hline & $\mathrm{M}_{12}-\mathrm{L}-\mathrm{M}_{(\mathrm{S})}$ & 0.00 & 19.28 & 0.00 & 0.00 & 0.00 & 0.00 & 0.00 & 19.28 \\
\hline & $\mathrm{M}_{12}-\mathrm{L}-\mathrm{M}_{(\mathrm{B})}$ & 0.00 & 0.00 & 37.50 & 4.17 & 8.33 & 0.00 & 0.00 & 50.00 \\
\hline
\end{tabular}

Table 4: Percentage of MAR in bacterial strains inhabiting in the mangrove assemblages and tidal channels (\%)

\section{Discussion}

In this study, the antibiotic resistance of bacteria isolated from most sampling sites (tidal channel and mangrove forest) to AMP, CEF and TMP was significantly stronger than to other antibiotics $(p<0.05)$. The previous research considered that bacterial resistance to TMP and COS was stronger than to NOR, oxolinic acid (OXLA) [15]. Moreover, Jalal, et al. reported that all isolates showed 100\% resistant to $\beta$-lactam and sulphafurazole antibiotics. These findings (including the previous researches and our results) indicate that the bacteria resistance to $\beta$-lactam and sulfonamide antibiotic is widespread in mangrove wetlands, which was perhaps attributed to several factors. The first may be that the $\beta$-lactam and sulfonamides have been extensively utilized in many shrimp farmings adjacent to mangroves, no exception is present for the Gaoqiao mangrove area in this study $[10,17,25]$. The differences in the percentage of bacteria resistance to various antibiotics may reflect the history of antibiotic usage [26]. The presence of antibiotics in the aquatic environment can induce the antibiotic resistance of bacteria, and the extent of antibiotic resistance is directly related to the dosage of antibiotic used [15]. Secondly, bacterial resistance to antibiotics also depends on their chemical structure and functional mechanism [27]. B-lactam is a family of enzyme inhibitor, of which the enzymes participate in the biosynthesis of the cell wall. The bacteria resistance to $\beta$-lactam antibiotics could be attributable to the bacterial capacity producting the $\beta$-lactamases 
and changing the affinity of penicillin binding proteins (PBPs) [28]. Schwartz, et al. reported that the occurrence of bacterial strains producing an extended spectrum of $\beta$-lactamases and other enzymes capable of hydrolyzing $\beta$-lactam antibiotics is increasing in both United States and Europe. The sulfonamides can reduce the reproduction of bacteria by restricting the dihydropteroate synthesis in the folic acid pathway, and the bacteria acquire usually antibiotic resistance after alteration of metabolic pathways $[29,30]$. The occurrence and increasing prevalence of sulfonamides-resistant bacteria and resistant genes in the environment were reported by Hsu, et al. and Colomer-Lluch, et al. [25,31]. Finally, the antibiotic residues in the environment may have inducted and maintained the bacterial resistance [2,27]. Our previous survey related to this research demonstrated that the mean level of sulfonamides in the water and sediments in these sampling sites were $0 \sim 8.6 \mathrm{ng} / \mathrm{L}$ and $0.1 \sim 12.6 \mu \mathrm{g} / \mathrm{kg}$, respectively [10], which was much lower than that in the shrimp farming constructed within the mangrove wetlands [15]. However, the sulfonamideresistant bacteria and genes have always been persistent even when the antibiotic agents exposed to low concentration or have been mineralized [7,32]. In general, the difference of bacterial resistance to antibiotics is affected synthetically by the history of antibiotic application, the residue of antibiotics in the environment, and chemical structure as well as functional mechanisms of antibiotics.

In the present study, the antibiotic-resistant bacteria were detected in the tidal channels, mangrove assemblages and the corresponding bare mudflats, and no significant differences in bacterial resistance to antibiotics were found among three levels in the tidal channel $(p>0.05)$. Similarly, the bacteria isolated from sediments in the mangrove assemblages revealed the same antibiotic-resistant profile as the corresponding bare mudflats $(p>0.05)$. Chelossi, et al. reported that a high percentage of resistant strains exist in both fish farms and control areas, and our previous research manifested that no significant differences in antibiotic resistance between the cultural ponds and corresponding control water source sites $[4,11]$. It is implied from this investigation and other researches that the antibiotic-resistant bacteria and genes caused by antibiotic overuse are extremely widespread by the horizontal and perpendicular transfer in the coastal wetlands including Gaoqiao mangrove area. Catch of exotic resistant genes is perhaps one of key factors for the widespread resistance of bacteria in aquatic environments $[2,26]$. It is confirmed that the exotic resistant genes can be horizontally transferred between bacteria by plasmid, transposons, bacteriophage, integron/gene cassette and other non-genetic factors [33-36]. Besides the catch of exotic resistant genes, the transfer of bacterial chromosome to the next generation (vertical gene transfer) was considered as one of the sources for the spread of antibiotic-resistant bacteria [33].

The percentages of antibiotic-resistant bacteria isolated from both bottom and surface sediment were significantly higher in the Avicennia marina assemblage than in the Aegiceras corniculatum assemblage $(p<0.05)$. Avicennia marina is a pioneer mangrove species inhabiting in low inter-tidal zone [37]. High level of bacterial resistance to antibiotics in Avicennia marina assemblage might result from the long-term submerging in seawater, favoring for the prevalence of resistance genes in Avicennia marina assemblage and accelerating the exchanges of the antibiotic-resistant bacteria and antibiotic-resistant genes between sediment and water $[26,38]$. In addition, it is supposed that the phenotypic resistance of bacteria versus the bacteria hosted in sediment from different mangrove forests is of interaction. Nevertheless, the opposite was considered by Mudryk, who reported a low level of bacterial resistance to tested antibiotics in low inter-tidal zone. As described in this study, no significant difference in antibiotic resistance between bacteria isolated from the bottom and surface sediment in mangrove assemblages $(p>0.05)$. The results from Mudryk, carried out near Sopot, Poland, showed that the bacteria isolated from the surface sand were more resistant to the tested antibiotics than those from the subsurface, whereas the fact that no significant difference in the bacterial resistance to antibiotics were found between bacteria isolated from the surface and the subsurface sand near Czołpino, along the southern coast of the Baltic Sea was revealed by Mudryk, et al. $[27,36,38]$.

Fluoroquinolones are synthetic bacteriostatic antibiotics with a wide spectrum against most gram-positive and gram-negative bacteria, depending on the inhibition of bacterial DNA gyrase or topoisomerase IV which are enzymes essential for DNA replication $[16,39]$. The presence of chromosome-encoded quinolone resistance and plasmid-mediated quinolone resistance (PMQR) has been reported by Rodríguez-Martínez, et al. [39]. The bacteria isolated from all samples in Aegiceras corniculatum assemblage and the tidal channels manifested their resistance to quinolone antibiotics despite a relatively low level, which was not detected in the Avicennia marina assemblage sediment in this study. However, this finding was different from the previous result provided by Jalal, et al. indicating that all of isolates were susceptible to ciprofloxacin in the tropical mangrove sediments in east coast peninsular, Malaysia. Poirel, et al. confirmed that PMQR can be spread horizontally among bacteria even the determinants only confer a low-level resistance to quinolones, which actually are favorable of the probability that the resistant genes transfer among species and encode in them. In addition, further studies need to confirm why the quinolones-resistant bacteria are absent in sediment in Avicennia marina assemblage where the bacteria reveal the high percentage of antibiotic resistance to most antibiotics [17,40].

Furthermore, the present study demonstrated that the percentage of MAR was higher in bacteria isolated from sediments in Avicennia marina assemblage than in Aegiceras corniculatum assemblage, and no significant difference in MAR of bacteria isolated from samples (water and sediment) were found among three levels in tidal channel $(p>0.05)$, with the same status for the percent of antibiotic resistance. MAR of bacteria to 3-4 antibiotics was more widespread in all sampling sites, which were slightly different from results obtained by Mudryk, et al., who confirmed that 6-9\% of the tested bacterial strains were resistant to 2-4 antibiotics even some microorganisms showed resistance to 5-11 antibiotics in southern coast of the Baltic Sea, although Mudryk reported that the majority of bacteria were resistant to 3-8 antibiotics. Bacteria can render many antibiotics used against them ineffective simultaneously, which is attributed to gene mutations and diverse combinations of mutations in genes, as well as horizontal genes transfer in some bacteria [36,38,41]. Moreover, the antibiotic family is also one of factor in the presence of multi-resistant bacteria 
[42]. The study on MAR in tropical mangrove sediments demonstrated that all bacterial isolates showed MAR value above $20 \%$. Multiple antibtiotic resistant bacteria in shrimp may reduce the efficacy of drugs in clinical treatment of diseases [17,26]. As pointed out by Smith, the contamination from the antibiotics or antibiotic-resistant bacteria in the environments can even result in the occurrence of multi-resistant human pathogens, therefore, the studies on the mechanism of MAR occurrence, diffusion and the potential harm to human correlative to environments are worth further conducting[43].

\section{Conclusions}

In this study, the incidence of bacterial resistance to 12 antibiotics was investigated in Gaoqiao mangrove area, China. The results reveal that as following:

(1) Antibiotic resistance of bacteria isolated from most samples (tidal channel and mangrove assemblages) to ampicillin, cefazolin and trimethoprim was significantly higher than to the other antibiotics $(p<0.05)$, which was attributed to the history of antibiotic usage and the antibiotic residue in the environment, and chemical structure as well as functional mechanisms of antibiotics.

(2) No significant differences in bacterial resistance to antibiotics were found among three levels in tidal channel ( $p>0.05)$, between the mangrove assemblages and the corresponding bare mudflats $(p>0.05)$, and between bottom and surface sediment in mangrove assemblages $(p>0.05)$. It is considered that the antibiotic-resistant bacteria and antibiotic-resistant genes were widespread in the way of the horizontal and perpendicular transfer in the coastal wetlands including Gaoqiao mangrove area.

(3) The percentages of antibiotic-resistant bacteria isolated from sediments were significantly higher in the Avicennia marina assemblage than that in the Aegiceras corniculatum assemblage $(p<0.05)$, which might result from the long-term submerging in seawater and the bacteria hosted in the sediment from different mangrove assemblages.

(4) The quinolone-resistant bacteria were found in all samples collected from Aegiceras corniculatum assemblage and the tidal channels but not in the sediment samples from the Avicennia marina assemblage.

(5) MAR of bacteria to 3-4 antibiotics was more widespread in all sampling sites. The higher MAR value in bacteria isolated from sediments samples was found in Avicennia marina assemblage compared to Aegiceras corniculatum assemblage, and no significant differences in MAR of bacteria isolated from samples (water and sediment) were detected among three levels in tidal channel $(p>0.05)$.

\section{Author's contribution}

In this article, Dr. Yu-Bin Zhang as the corresponding author was responsible for the design and instruction in this research, and in charge of revision for the manuscript. In this research, Dr. Hang-Qing Fan was responsible for the data treatment and statistical analysis, and supported part of funding, Dr. Xing-Li Sun provided the laboratory and experimental instruments, others participated in the experimental works.

\section{Acknowledgements}

This study was supported by Public Science and Technology Research Funds Projects of Ocean, China (201305021, 201505028), Scientific and Technological Projects of Guandong Province (2013B020309011), China. The authors thank Dr. Xing-Hai Zhang of Florida Atlantic University for his wonderful polishing this manuscript.

\section{References}

1. Pruden A, Larsson DG, Amėzquita A, Collignon P, Brandt KK, et al. (2013) Management Options for Reducing the Release of Antibiotics and Antibiotic Resistance Genes to the Environment. Environ Health Perspect 121: 878-85.

2. Sarmah AK, Meyer MT, Boxall AB (2006) A global perspective on the use, sales, exposure pathways, occurrence, fate and effects of veterinary antibiotics (VAs) in the environment. Chemosphere 65: 725-59.

3. Uchida K, Konishi Y, Harada K, Okihashi M, Yamaguchi T, et al. (2016) Monitoring of Antibiotic Residues in Aquatic Products in Urban and Rural Areas of Vietnam. J Agric Food Chem 64: 6133-8.

4. Zhang YB, Li Y, Sun XL (2011) Antibiotic resistance of bacteria isolated from shrimp hatcheries and cultural ponds on Donghai Island, China. Mar Pollut Bull 62: 2299-307.

5. Le TX, Munekage Y (2004) Residues of selected antibiotics in water and mud from shrimp ponds in mangrove areas in Viet Nam. Mar Pollut Bull 49: 922-9.

6. Thuy HT, Nga le P, Loan TT (2011) Antibiotic contaminants in coastal wetlands from Vietnamese shrimp farming. Environ Sci Pollut Res Int 18: 835-41.

7. Martinez JL (2009) Environmental pollution by antibiotics and by antibiotic resistance determinants. Environ Pollut 157: $2893-902$.

8. Xi X, Wang M, Chen Y, Yu S, Hong Y, et al. (2015) Adaption of the microbial community to continuous exposures of multiple residual antibiotics in sediments from a salt-water aquacultural farm. J Hazard Mater 290: 96-105.

9. Lalumera GM, Calamari D, Galli P, Castiglioni S, Crosa G, et al. (2004) Preliminary investigation on the environmental occurrence and effects of antibiotics used in aquaculture in Italy. Chemosphere 54: 661-8.

10. Li Y, Li Q, Zhou K, Sun XL, Zhao LR, et al. (2016) Occurrence and distribution of the environmental pollutant antibiotics in Gaoqiao mangrove area, China. Chemosphere 147: 25-35.

11. Chelossi E, Vezzulli L, Milano A, Branzoni M, Fabiano M, et al. (2003) Antibiotic resistance of benthic bacteria in fish-farm and control sediments of the Western Mediterranean. Aquaculture 219: 83-97.

12. Nawaz M1, Khan SA, Tran Q, Sung K, Khan AA, et al. (2012) Isolation and characterization of multidrug-resistant Klebsiella spp. isolated from shrimp imported from Thailand. Int J Food Microbiol 155: 179-84. 
13. Vaseeharan B, Ramasamy P, Murugan T, Chen JC (2005) In vitro susceptibility of antibiotics against Vibrio spp. and Aeromonas spp. isolated from Penaeus monodon hatcheries and ponds. Int J Antimicrob Agents 26: 285-91.

14. Tendencia EA, de la Peña LD (2001) Antibiotic resistance of bacteria from shrimp ponds. Aquaculture 195: 193-204.

15. Le TX, Munekage Y, Kato S (2005) Antibiotic resistance in bacteria from shrimp farming in mangrove areas. Sci Total Environ 349: 95-105.

16. Takasu H, Suzuki S, Reungsang A, Pham HV (2011) Fluoroquinolone (FQ) contamination does not correlate with occurrence of FQ-resistant bacteria in aquatic environments of Vietnam and Thailand. Microbes Environ 26: 135-43.

17. Jalal KCA, Fatin NUT, Mardiana MA, Akbar-John B, Kamarruzzaman YB, et al. (2010) Antibiotic resistance microbes in tropical mangrove sediments in east coast peninsular, Malaysia. Afr J Microbiol Res 4: 640-45.

18. Lin G, Lu W (2011) Investigation of plant resources in Zhanjiang Gaoqiao mangroves and the surrounding regions, Guangdong province (in Chinese). Guangdong Fore Sci Tech 27: 38-43.

19. Zou F, Zhang H, Dahmer T, Yang Q, Cai J, et al. (2008) The effects of benthos and wetland area on shorebird abundance and species richness in coastal mangrove wetlands of Leizhou Peninsula, China (in Chinese). Forest Ecol Manag 255: 3813-8.

20. Guizhu C, Shenyu M, Jinhong Z (2000) Ecological study on the mangrove forest in Zhanjiang Nature Reserve, Guangdong (in Chinese). J Guangzhou Nor Univ (Nat Sci Ver) 21: 65-9.

21. Tang Y, Yu S (2007) Spatial zonation of macrobenthic fauna in Zhanjiang Mangrove Nature Reserve, Guangdong, China (in Chinese). Acta Ecol Sin 27: 1703-14.

22. Cao Z, Ye Y, Lu C, Zheng F (2004) Preliminary studies on effects of restored mangroves on coastal soils (in Chinese). Ecol Sci 23: 110-3.

23. Aaronson S (1970) Experimental Microbial Ecology. Academic Press, New York, USA .

24. Webster LF, Thompson BC, Fulton MH, Chestnut DE, Van Dolah RF, et al. (2004) Identification of sources of Escherichia coli in South Carolina estuaries using antibiotic resistance analysis. J Exp Mar Biol Ecol 298: 179-95.

25. Hsu CH, Wang SC, Liu JK (1992) Succession of bacterial drug resistance as an indicator of antibiotic application in aquaculture. J Fish Soci Taiwan 19: 55-64.

26. Kümmerer K (2009) Antibiotics in the aquatic environment-a review-part II. Chemosphere 75: 435-41.

27. Mudryk ZJ (2002) Antibiotic resistance among bacteria inhabiting surface and subsurface water layers in estuarine lake Gardno. Pol J Environ Stud 11: 401-06.

28. Tang SS, Apisarnthanarak A, Hsu LY (2014) Mechanisms of beta-lactam antimicrobial resistance and epidemiology of major community- and healthcareassociated multidrug-resistant bacteria. Adv Drug Deliver Rev 78: 3-13.

29. Schwartz T, Kohnen W, Jansen B, Obst U (2003) Detection of antibiotic-resistant bacteria and their resistance genes in wastewater, surface water, and drinking water biofilms. FEMS Microbiol Ecol 43: 325-35.

30. Blair JM, Webber MA, Baylay AJ, Ogbolu DO, Piddock LJ (2015) Molecular Mechanisms of Antibiotic Resistance in Bacteria. Bennett's Principles and Practice of Infectious Diseases (8th Edn). Philadelphia, 31-5.

31. Colomer-Lluch M, Calero-Cáceres W, Jebri S, Hmaied F, Muniesa M, et al. (2014) Antibiotic resistance genes in bacterial and bacteriophage fractions of Tunisian and Spanish wastewaters as markers to compare the antibiotic resistance patterns in each population. Environ Int 73: 167-75.

32. Gao P, Mao D, Luo Y, Wang L, Xu B, et al. (2012) Occurrence of sulfonamide and tetracycline-resistant bacteria and resistance genes in aquaculture environment. Water Res 46: 2355-64

33. Davison HC, Low JC, Woolhouse ME (2000) What is antibiotic resistance and how can we measure it? Trends Microbiol 8: 554-9.

34. Dantas G, Sommer MO (2012) Context matters - the complex interplay between resistome genotypes and resistance phenotypes. Curr Opin Microbiol 15: $577-82$.

35. Alanis AJ (2005) Resistance to antibiotics: are we in the post-antibiotic era? Arch Med Res 36: 697-705.

36. Mudryk Z, Perliński P, Skórczewski P (2010) Detection of antibiotic resistant bacteria inhabiting the sand of non-recreational marine beach. Mar Pollut Bull 60: 207-14.

37. Kathiresan K, Bingham BL (2001) Biology of mangroves and mangrove Ecosystems. Advances in Marine Bio 40: 81-251.

38. Mudryk ZJ (2005) Occurrence and distribution antibiotic resistance of heterotrophic bacteria isolated from a marine beach. Mar Pollut Bull 50: 80-6.

39. Rodríguez-Martínez JM, Cano ME, Velasco C, Martínez-Martínez L, Pascual A (2011) Plasmid-mediated quinolone resistance: an update. J Infect Chemother 17: 149-82.

40. Poirel L, Cattoir V, Nordmann P (2012) Plasmid-Mediated Quinolone Resistance; Interactions between Human, Animal, and Environmental Ecologies. Front Microbiol 3: 24.

41. Croucher NJ, Harris SR, Fraser C, Quail MA, Burton J, et al. (2011) Rapid pneumococcal evolution in response to clinical interventions. Science 331: 430-4.

42. Toprak E, Veres A, Michel JB, Chait R, Hartl DL, et al. (2012) Evolutionary paths to antibiotic resistance under dynamically sustained drug selection. Nat Genetics 44: 101-140.

43. Smith P (2007) Antimicrobial use in shrimp farming in Ecuador and emerging multi-resistance during the cholera epidemic of 1991: A re-examination of the data. Aquaculture 271: 1-7. 


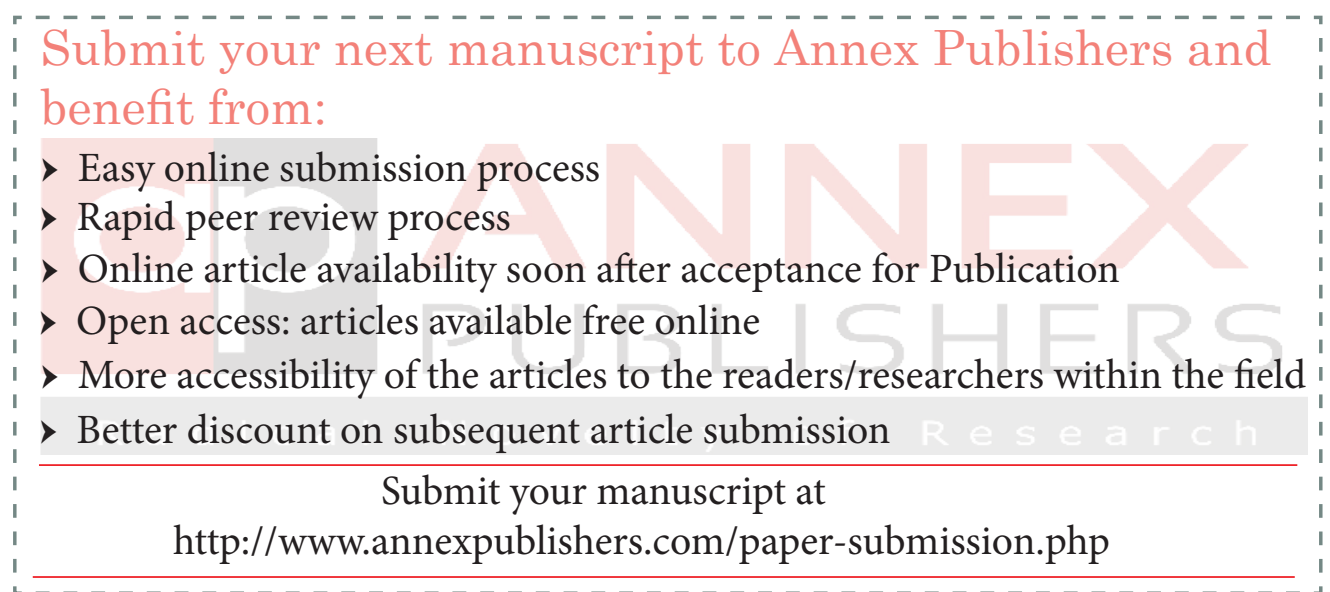

